\title{
HAK-HAK ASASI MANUSIA DALAM HUKUM ISLAM
}

\section{Tutik Hamidab}

\section{Sekilas tentang HAM}

Hak-hak Asalsi manusia (funclamental human rights) secara obyektif bertujuan mulia. Ia memberi hak-hak clasar kepacla manusia tanpa membedakan asal-usulnya, baik ras, warna kulit ,jenis kelamin, balhasa maupun agama. Ia aclalah hak-hak yang inheren pacla manusia, yang hanya dengan terpenuhinya hak-hak itu manusia clapat mencapai tingkat perkembangan yang baik. Dalam Mukacddimah perjanjian Internasional Hak Sipil clan Politik clari PBB clirumuskan, "These Rights derive from the inberent dignity of the buman person "(Hak-hak ini berasal dari mautabat yang melekat dalam diri manusia). Sebab itu, hak-hak clasar itu harus diberikan tanpa boleh clihalang-halangi attaupun clihambat.

Hak-hak clasar itu clalam runusannyal yang paling awal clan paling jelas, clikemukakan oleh John Locke (1632-1705), aclalahi hak atas hiclup, kebebasan clan kepemilikan (life, liberty and property) serta pemikiran bahwa penguasal harus memerintah clengan persetujuan rakyat (goverment by consent). 'Rumusan Locke tersebut merupakan prototype pemikiran filsáfát Masáa Pencerahan (enlightenment) yang menganut aliran liberalisme (klasik).Pemikiran tersebut, secara ringk:ils, dikemukakan bahwal para filsáfat Masal pencerahain, walaupun berbecla clalam penafsiran, semuianyal membayangkan adlanyal suatu kealdalan yang manusia hidup clalam keaclaan alam (state of nature). Manusia dalam keadlaan alam ini sama clerajatnya (equal), semua tunduk padla Hukum Alam clan semua memiliki hak-hak alam. Pacla suatu sáat, manusia, clengan memakai rasionyal, akan sampai pacla kesimpulan bahwa untuk menjamin terlaksanannya hak-hak alam itu, keaclaan alam perlu clitinggalkan clan cliganti clengan kehiclupan bernegara berdasarkan suatu kontrak sosial antara penguasa clan masyarakatt. Ini clinamakan Teori Kontrak Sosial.?

Filsuf-filsuf Masaa Pencerahan yang lain, yang pemikirannyal menjadli inspirasi untuk perjuangan kemerdekalan altau revolusi, aclalah Montesquieu (16891755) yang menekankan pembagian kekuasalan sebagai sarana menjamin hak-hak manusia, suatu sistem yang kemudian clikenal clengan istilah trials politica. Filsuf lain, Jean Jacques Roussealu (1712-1778), menekiankan perlunya kebebasan. Pemikiran John Locke menjadli pegangan bagi rakyat Amerika ketika memberontak melawan penguasa Inggris pada 1776, seclanng pemikiran Jean-Jacques Rossealu menjadi inspirasi bagi rakyat prancis untuk memulai revolusinyal

palda 1789. ${ }^{3}$

Akan tetapi beberapal abad sebelum Masal Pencerahan, hak asasi manusia sudah dipermasallalhkan di Inggris. Adlanya Perjanjian Agung (Magna Cauta) pacla 15 Juni 1215 antara Rajaj John clengan para bangsalwan yang berisi jaminan hak-hak pilitik clan sipil yang mendasar, sampai sekarang dianggap sebagai tonggak sejarah dalam perkembangan demokrasi di Barat. 4

Hak-hak clasarl tersebut kemudian dicantumkan keclalam beberapa piagam. Di Inggris hak itu 
diundangkian dalam 'Bill of Right (Unclang-unclang Hak,1689), yang cliterima sattu tahun sesudah Parlemen berhasil mengusir Rajal James II dan mengundlang putrinyal beserta suaminya, William of Orange, untuk menduduki talhta Kerajian Inggris (the Glorius Revolution of 1688). Hak-hak yang dirumuskan tidlak boleh dilanggar oleh Rajja sekalipun. ${ }^{5}$

Deklarassi Kemerclekalan Amerikạl Serikat páda 6 Juli 1776 (Declaration of Independence of the United States) menuat penegasan bahwal setiap orang dilahirkan dalam persamaan clan kebebasain clengan hak untuk hiclup clan mengejar kebahagialan, serta keharusan mengganti pemerintahan yang tidak mengindallikan ketentuanketentuan clasars tersebut.

Di Perancis, Deklarasi Hak-hak Manusia clan Warganegaral (Declaration des droits de I'bomme et ducitoyen,1789), suatu naskalh yang clirumuskan pala awal revolusi rakyat Perancis melawan raja-raja Bourbon. Deklarasi ini mencanangkan hak atals kebebasan (liberte), kesamain (egalite) dan kesetiakawanan (Fraternite).

Konsep hak-halk asasi terus bergulir menjadi wacana publik di negaral-negara Eropal
Hak asasi manusia tidak lagi monopoli dunia Barat. la súdah menjadi universalirumusan hak-hak asasi manusia oleh sebagaian besar ummat dianggap universal, sekalipun dapat diwarnai secara khusus berdasarkan kebudayaan dan agama ma sing-masing negara. ${ }^{7}$ Namun kekhususan nasional atau regional serta berbagai latar belakang sejarah, budaya dan agama tidak boleh menghalangi perlindungan dan kemajuan hak asasi manusia dan kebebasan asas: 8
48 negara memberi persetujuan, tiga negaral menolak clan clelapan negaráa abstain. Karena sifatnya deklarasi, ial ticlak mengikat secaral yuridis, hanyal secara moral. Deklarasi mempunyai pengaruh moral, politik dan edukatif yang sangat besar. Ia melambangkan "komitmen" moral dunia internasional pada hak-hak asassi manusia sekaligus pedoman standar minimum yang clicita-citakan umat manusia untuk menciptakan clunia yang lebih sempurna..

Bera wal dari Deklarasisi Hak Asasi Manusial pada talhun' 1948(Universal Declaration of Human Rights), yang kemudian clijabarkan clalam clua perjanjian internasional, juga clalam sidlang umum PBB, clua puluh tahun kemudian, yaitu tahun 1966, clan clisusul dengan cleklarasi-cleklarasi yang lain, seperti Helsinki Accord (1975) di Eropa; African Charter on Human and Peoples'(Piagam Afrika mengenai Hak Manusia clan Bangsal-bangsai, 1981); Cairo Declaration on Human Rights in Islam (Deklrasi Kaliromengenai Hak Asasi clalam Islam,1990); Bangkok Declaration, 1993 dan lain-lain serta cliclorong oleh proses globalisasai yang sedang kita alami sekarang, hak asasi Barat, Timur maupun Amerika, hingga seusai perang Dunia II, timbul kehendak merumuskan hak-halk asasi yang diakui cliseluruh clunia sebagai stanclar bagi perilaku manusia secara universal. Ușạal pertama kearrah standar setting dimulai oleh Komisi Hak Asalsi (Commision of Human Rights) yang cliclirikan oleh. PBB pada 1946. Hasil pekerjalan Komisi ini, Universal Declaration of Human Rights, clual tahun kemudian, Desember 1948, cliterima secara aklamasi oleh negaratnegara yang pada saat itu tergabung clalam Perserikattan Bangsà-Bangsá, dengan caltattạn băahwa manusia tidak lagi monopoli clunia Barat. Ia sudah menjäliuniversăal, rumusan hak-hak asasi manusia oleh sebagaian besar ummat dianggap universal, sekalipun dapat diwarnai secara khusus berdasarkan kebudayaan dan agama masing-masing negara.' Namun kekhususan nasional attau regional serta berbagai latar belakang sejarah, buclaya dan agama tidak boleh menghalangi perlindungạn dan kemajuan hak asalsi manusia dan kebebassan asasisi.

Sebagai ilustrasi acla baiknya clisebutkan beberapa hak asasi manusia yang climuat clalam 
perjanjian PBB mengenai Hak Sipil clan Politik (The International Convenant on Civil and Political Rights) dan Perjanjian PBB mengenai hak Ekononi, Sosial, clan Buclaya (The Intemational Convenant on Economic, Social and Cultural Rights). Hak Sipil clan Politik mencakup antara lain: right to life - hak atas . hiclup (Pasal 6); right to liberty and security of person. - hak atas kebebasan clan keamanan clirinya (Pasal 9); right to equality before the court and tribunalshak atas kesamalan climuka baclan-baclan peradilan (Pasal 14); right to freedom of thought, consience and religion - hak atas kebebasan berfikir, kesaclaran nurani clan agama (Pasal 18); right to bold opinions without interferencehak mempunyai penclapat tanpa gangguan (Pasal 19); right to peaceful assembly - hak atas kebebasan berkumpul secaral clamai (Pasal 21); right to freedom of assosiation - hak berserikat (Pasal 22). Haks Ekonomi, Sosial clan Buclaya mencakup antara lain: right to work - hak atas pekerjalan (Pasal 6); right to form trade union hak membentuk serikat kerja (Pasal 8); right to social securrity - hak atas pensiun (Pasal 9); right to an adequate standard of living for bimself and family, anchucling adequate food, clotbing and bousing - hak atas tingkat kehidupan yang layak bagi dirinya clan keluarganya, meliputi pangan, pakaian clan perumahan (Pasal 11); right to eclucation - hak atas pendidikan (Pasal 13).

\section{HAM dalam Pandangan Ulama'}

Dari uraian diatas, jelaslah bahwa clari cikal bakal sampai perkembangannya, HAM aclalah procluk buclaya Barat. Formulasi HAM clalam Islam baru clicleklarasikan pacla tahun 1990 di Kairo (Cairo Declatration on Human Rights in Islam). Meskipun begitu, ticlak clapat cli ambil kesimpulan bahwa cli clalam Agama Islam ticlak clikenal HAM, sebagaimana diklaim oleh Alasclair Mac Intyre, bahwa gagasan tentang hak ticlak clapat clitemukan clalam setiap masyarakat, yang diclukung oleh kenyataan ticlak aclanya pernyataan clalam bahasá zaman kuno atau zaman pertengahan yang secara tepat clapat cliterjemahkan clengan pernyataan "hak" hingga hampir akhir abad pertengahan, ticlak clapat diterima."

Akan tetapi ticlak clapat clipungkiri bahwava kata, hak kurang populer dibandingkan clengan kata kewajiban clalam khazanah literatur Islam. Hal ini karena kewajiban terclapat hak orang lain. Jikal semua orang melakukan kewajibannya, maka clisisi lain hak semua orang suclah terpenuhi.

Konsep HAM, clalam panclangan Ulama'10, bisa clisejajarkan clengan konsep maqasid al-syari'ah. Yaitu syari'ah Islam clisyalriatkan clalam rangka melinclungi kemaslahatan manusia. Suclah tentu, yang dimaksud adalah melinclungi kepentingan, keselamatan clan kesejahteralan manusia baik clalam hiclup di clunia maupun di akhirat. Kenaslahatan clapat di wujuclkan apabila lima unșur pokok clapat cliwujuclkan clan clipelihara. Lima unsur pokok ini menempati tingkat funclamental (darmiyjab). Kelima unsur pokok tersebut adalah, agama (al-din), jiwa (al-nafs), akal (al-agl), keturunan (al-nasl) clan harta (mal). Ticlak terwujuclnya kelima unsur pokok tacli clapat merusak tatanan kehiclupan manusia cli. clunia clan di akhirat. Kelimai unsur pokok tersebut, kemudian cliiringi clua tingkat di bawahnyal, yaitu pemenuhan kepentingan (bajjiayyab), yaitu upaya-upaya yang bertujuan menghilangkan kesulitan atau menjaclikan pemeliharaan kelima unsur tadi lebih 
baik lagi. Jika tingkat keclua ini diabaikan, memang tidak sampai merusak tatanan kehiclupan, tetapi akan muncul kesulitan bagi manusia untuk mewujuckan tujuannya. Tingkat yang ketiga adalah Tahsiniyyah, yaitu upaya-upayal yang berhubungan erat clengan dimensi etika dan estetika clalam menyempurnakan upayal perwujudan dua tingkat diatasnya, daruriyyab, bajjiyyab dan tabsiniyyab membentuk tatanan kehidupan manusia yang selamat, sejahtera, di dunia dan di akhirat, dan- yang terpenting- mewujudkan dan memelihara kesejatian diri manusial.

Elaborasi kelima unsur pokok tacli menjadikian sama clan sebangun dengan formulasi HAM PBB. Perlindungan terhadap agama, mengimplikasikan hak kebebasan beragama; perlinclungan kepada jiwa, mengimplikasikan hak untuk hidup tanpa penganiayaan; perlindungan kepada akal; mengimplikasikan hak untuk mendapatkan penclidikan, berfikir clan berpenclapat; perlinclungan kepada keturunan, mengimplikasikan kepacla hak untuk memilih pasangan hiclup clan menikah dan perlindungan kepada harta, mengimplikasikan hak untuk memiliki clan bekerja. Karena itu, menurut DR.Massykuri Abclillah, mayoritas intelektual Muslim Indonesia menerima formulasi HAM PBB clan menganggapnya sejalan dengan ajaran Islam. "Balkkan lebih jauh dari sekeclar menerima, menurut Greg Barton, gerakan Neo Moclernisme Islam, dimana di Indonesia tokolinya aclalah Abclurrahman Wakhid dan Nurcholis Madjid, berpandangan, bahwa apa yang menjadi kepedulian Barat selama ini,mengenai HAM, demokrasi, pemisahan gereja dari negara, sesungguhnya aclakah kepedulian Islam sendiri dengan kadar yang sama besarnya dengan Barat. ${ }^{12}$

\section{Problematika HAM dalam Hukum Islam}

Bagaimana menjamin terwujudnya serta terpeliharanya HAM tersebut? Dalam hal ini Bassam Tibi mengemukakan, "rights can only be institutionalized in legal contex ${ }^{13}$ - hak-hak hanya bisa dijamin clalam sebuah hukum. Sejalan clengan Tibi, Jeremy Bentham mengemukakan, "right is a cbild of law, from real laws come real rights' ${ }^{\prime \prime}$ - hak adalah anak hukum, dari hukum-hukum yang sejati cliperoleh hak-hak sejati. Dengan clemikian HAM clan hukum secara intrinsik bertali temali saltu samá láin.

Bertitik tolak dari paracligma diatas, muncul problem yang serius. Sementara mayoritas intelektual Muslim berpenclapat bahrwa formulasi HAM sejalan clengan ajaran Islam, namun Hukum Islam ticlak memberi tempat yang sama antara Muslim dan nonmuslim, laki-laki dan wanita. Hal mana clalam formulasi HAM dianggap cliskriminasi. Menurut Abdullah Ahmed An-Na'im, perbeclaan hukum atas dasar agama dan gender bisa dilihat misalnya, dalam hal hukum pidana, saksi clan keluarga15. Sejalan dengan An-Na'im, Tabancleh mengemukakan bahwa dalam subyek agama dan gender, perbeclaan-perbedaan ketentuan yang mengarah kepada diskriminasi sangat menonjol dalam Hukum Islam.16 Sementara itu, perbedalan etnis , suku bangsa ataupun bahasa tidak menjacli clasals pertimbangan dalam penentuan Hukum Islam.

Sebagai ilustrasi bisa disebutkan disini, perbedaan hukum antara laki-laki dan wanita, misalnya dalam hal kesaksian, kesaksian dua wanita dianggap sebanding dengan kesaksian seorang laki-laki. Dalam hal waris, hak cerai, poligami clan menikah dengan non-muslim.

Menurut metodologi Hukum Islam (usul al-figb), 
hukum-hukum yang dijelaskan secara eksplisit dalam al-Qur'an attau had dis sahihi adalah hudah tidak mungkin dirubah lagi, la ijtibada fi ma fibi nas. Ia merupakan hukum yang sudah final, berharga mati.Demikian pula hukum-hukum yang berdasarkan ijma'. Metodologi Hukum Islam tersebut menjadi rujukan mayoritas Ulama' Inclonesia. Hal ini bisaa dilihat, misalnya dalam Kompilasi Hukum Islam (KHI) tampak begitu berkembang. Hal itu ditunjukkan antaral lain dengan dilakukannya reinterprestasi dalam perkạra poligami; memperketat syarat cerai talak, memberi hak cerai gugat kepada istri, mensyaratkan adanya persetujuan istri dalam kasus rujuk, mengesalhkan kawin hamil yang merupakan upaya kompromi dengan adat dan lain-lain. Akan tetapi dalam bidang kewarisan, KHI belum melangkah dari ketentuannya yang baku.Misalnya, bagian anak perempuan tetap setengah dari bagian anak laki-laki. Hầl inî sangat müngkin disebabkan, bidang kewarisan pada umumnyà sudah disebutkan secará rinci dalam al-Qur'an, sehinggà padla umumnya Ulama' berpandangan tidak mungkin lagi melakukan reinterprestasi. Berbeda dengan bidang perkawinan dimana banyak hal-hal yang ticlak dijelaskan secara rinci dalám al-Qur'an.

Dengan demikian, terdapat problem yang mendasar, jika hukum Islam dihadapkan kepadla HAM. Paling sedikit, sebagaimana disebutkan disini, adalah pada hukum keluarga: Problem tersebut adalah konsep mayoritas Ulama' tentang ayate-ayat gotb'i. Dalam pandangan merakal, ayatt-ayat gotb' $i$ itu sudah enumeratif dan bersifat absolut. Wilayah ini, dari masal ke masa, selalu menjadi pergulatan ahli-ahli hukum (Fugaba'). Antara berpegang kepada nas sesuai dengan literalnya (lafad) atau menukik kepada substansi yang ditunjukkan nas (mal waraala al-lafald). Muncullah beberapa tawaran metode memahami nas dalam upayal merespon perkembangan kemanusiaan. Sebut saja misalnya, beberapa nama yang kini menghiasi wacana Islamic Studies, Fazlur Rahman, Mohammed Arkoen, Abdullahi Ahmed An-Na' im, Riffat Hasan dan di Indonesia, Nurcholish Madjicl, Masdar Farid Mas'udi dan lain-lain.
Mengakhiri uraian ini, Penulis mengemukakan pemikiran tentang ayat-ayat gotb' $i$ yang berbeda' dengan mayoritas Ulama' yang dikemukakan oleh AsSyatibi (W.790/1388),nama lengkapnya Abu Ishaq Ibrahim ibn Muhammad al-Lakhmi al-Garnati asySyatibi dalam kitab al-Muwafaqotnyal, yang pada hemat penulis sangat signifikan untuk dielaborasi lebih lanjut.

Menurut asy-Syatibi, sangat sulit untuk memastikan apakah suatu ayat gotb' $i$ atau tidak. Sebab untuk memastikan suatu ayat bersifat 'gotb' $i$ diperlukan seperangkat petunjuk yang tentu harus bersifat gotb'ijugat. Seperangkat petunjuk tersebut antara lain, adalah analisis kebahalsalan berikut sastranya dan analisis qawaid, usuliyyab, seperti soal isytirak, majaz, idlmar, takbsis, itlaq-tagyid, tagdim-ta'kbir dan nasikb-mansukb. Padalaal semual petunjuk ini sifatnya zanni. Semua orang pasti sepakat bahwal zannitidak cukup syarat untuk menentukan ke-qotb'i-an suatu ayat tertentu. Sesuatu yang perangkat petunjuknyal bersifat zanni, tidak bisa tidak, semestinyal bersifat zanni juga. Dengan demikian bisa dipastikan bahwa suatu ayat tertentu tidak bersifat gatb'i dalalab. Berikut ini pernyatialan Asy-Syatibi.17 :

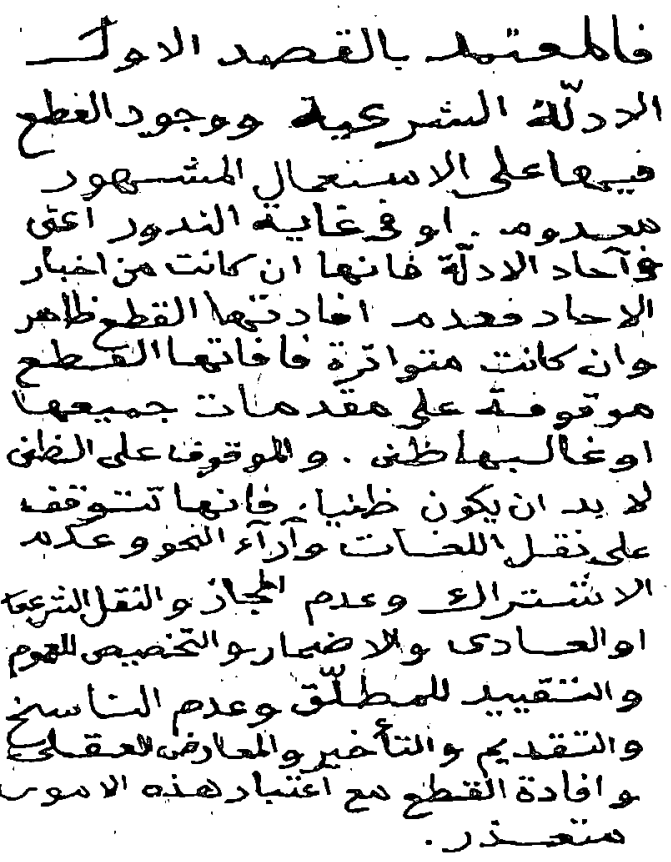


(Adapun yang menjadi pegangan, pertama-tama, adalah dalil-dalil syar'i. Dan dalil qoth'i menurut pengertiannya yang masybur adalab tidak ada. Adalah sangat tidak mungkin, clalil abad (satuan, suatu ayat) bersifat qoth'i. Jika dalil itu merrupakan khabar ahad, maka tidak qoth'i-nya adalah jelas. Sedang jika dálil itu mutawatir, maka sifat qath'i-nya bergantung kepacla sejumlah petunjuk (muqaddimat) yang kesemuanya atau kebanyakan clari padanya bersifat zanni. Sesuatu yang bergantung kepacla zanni, tidak bisșa tidak, bersifat zanni juga. Petunjuk-petunjuk itu adalah analisis kebahasaan, gramatika, tidak adanya isytirak, majaz, serta analisis syar'i atau adat. Idlmar, takbsis, taqyid, tidak adanya nasikh, taqdim-ta'kbir seita kelurusan logika. Memastikan qath'i berdasarkan parameter diatas adalah tidak mungkin).

Menurut asy-Syatibi, cara untuk memastikan bahwa suatu ayat qath' $i$ adalah dengan menganalisis sejumlah ayat sehingga bisa diperoleh suatu pengertian yang searah clari ayat-ayat tersebut. Kolaborasi sejumlah ayat tersebut menunjukkan bahwa pengertian yang terkandung di dalamnya bersifat pasti dan tak terbantah. Ibaratnya, ia mutawatir ma'nawi dan memiliki kekuatan yang tidak dimiliki oleh dalil ahad (satuan, ayat tertentu). Perhatikan pernyataan asy-Syatibi berikut ini 18 :

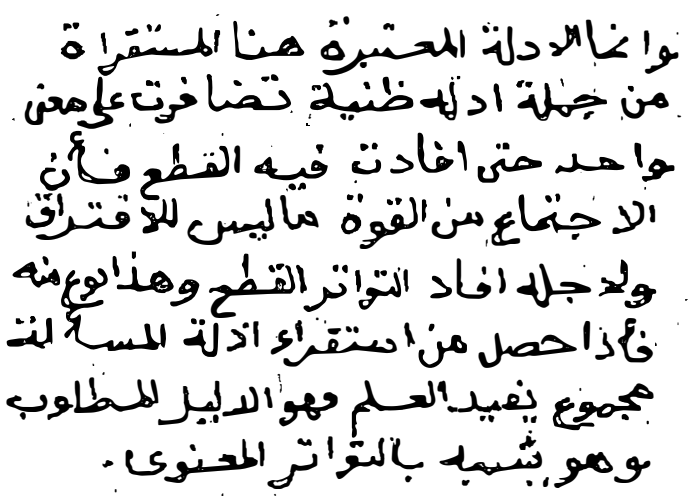

(Aclapun dalil-calil yang mu'tabar aclalah dalil-clalil yang diperoleh lewat kerja istiqra' dari sejumlah dalildalil zanni yang menunjukkan kesearahan arti, sehingga bersifat qath'i. Karena bagaimanapun, kollektifitas (ijtima') memiliki kekuatan yang ticlak dimiliki kesendirian (iftiraq). Sebáb itulah mutawatir itu berfaedah wath'i. Seclang hal ini serupa dengan mutawatir. Jika dihasilkan suatu kesimpulan clari sejumlah clalil, maka itulah dalil yang clicari clan demikian itu berarti mutawatir ma'nawi).

Kerja istiqra' ini bisa clicontohkan dengan ayat yang memerintahkan mengerjakan salat misalnya, seperti ayat berikut ini :

$$
\therefore \text {. } \Rightarrow 111 .
$$

Ayat ini ticlak bisa langsung clinyatakan mengandung pengertian qath'i bahwa salat itu wajib. Sebab perangkat-perangkat inclikasi yang menunjukkan hail itu bersifat zanni. Tetapi dengan digabungkan dengan berbagai ayat yang lain, seperti perintah mengerjakan salat, pujian terhadap orang yang mengerjakan serta ancaman terhadap orang yang meninggalkan, penjelasan hikmah salat clan lain-lain, bisa diambil kesimpulan bahwa perintah mengerjakan salat adalah wajib. Jacli pengertian qath'i bahwa melakukan salat adalah wajib ticlak berdasarkan satu-clua ayat saja, melainkan dari penalaran incluktif (istiqra') terhaclap sejumlah ayat."

Bukankah pemikiran dan argumentasi asy-Syatibi ini ménarik untuk dicermati ? Jika pemikirannya diterima, maka ketegangan clalam Hukum Islam, khususnya tuduhan diskriminasi terhadap wanita clan non-muslim bisa dihindarkan tanpa perlu acla tucluhan telah meninggalkan ayat-ayat al-qur'an.

Wallahu 'a'lam bi al-sawab.

\section{End Notes :}

(1) Miriam Bucliarcljo, Menggapai Keclaulatan untuk Rakyat; (Bandung : Mizan, 1998), h.43

(2) Ibid, Lihat juga Harun Hadiwiyono, Sari Sejarab Filsafat Barat 2, (Yogyakarta : Kanisius, 1980), h.4962

(3) Ibid

(4) Nurcholish Macljid, Islam Agama Kemanusiaan, 
Membangun Tradisi dan Visi Baru Islam Indonesia, (Jakartal : Palramadlina, 1995), h.211. Lihat jugal Miriam Budiarcljo, Menggapai Kedaulatan..., h.42.

(5) Ibid

(6) Miriam Budliarcljo, Menggapai Kedaulatan...., h.489 .

(7) Ibid, h.50

(8) Ibid, h.86

(9) Dikutip clari Masykuri Abclillah, Demokrasi di Persimpangan Makna, (Yogyakarta : Tiara Wacana, 1999), h.97

(10) Lihat misalnya, Abcl. al-Wahhab Khallaf, Ilm Usul al-Fiqb (Kuwait ; Dar al-Qallam, 1978), h.199. Abu Zahrah, Usul al-Figh, (Darr al-Qaalam al-Arabi, t.t.) h.364. Ali Yafie, "Hak Individu dan Masyarakat dalam Khazanab Pesantren" clalam Pesantren, Vol.IV, No.1 1987 h.6.

(11) Masykuri Abclillah, Demokrasi.... h.110

(12) Greg Bartón, "Inclonesia's Nurcholish Macljicl and Abclurrahman Wachid as Intellectual Ulama' : The Meeting of Islamic Tradlitionalism and Modernism in Neo-Modernist Thought". Studia Islamika, Vol.4, No.1, 1997, h.66-7.

(13) Bassam Tibi, "Islamic Laww/Shari'a and Human Rights : International Law and International Relations" dallam Tore Lindholm and Karri Vogt (edl.) Islamic Law Reform and Human Rights, (Oslo : Nordic Human Rights Publication, 1993), h.75.

(14) Dikutip oleh Parveen dalam bukunyal, Human Right in Islam, 17

(15) Abclullahi Ahmed An-Na'im, Toward an Islamic Reformation: Civil Liberties, Human Rights and International Law (Syracuse : Syracuse University Press, 1990), 90, 163.

(16) Dikutip oleh Akh. Minhaji, "Hak-hak Asasi Manusia clalam Hukum Islam : Penafsiran Baru tentang Posisi Minoritas Non-Muslim" Jurnal Ulumul Qur'an. (17) Abu Ishaq asy-Syatibi, al-Muwwafaqat fi Usul alAbkam Jilid I, (Darr al-Rasyad al-Hadlisah, t.t.) h. 14
(18) Ibid

(19) Ibid

\section{Daftar Pustaka :}

Miriam Budiarcljo, Menggapai Kedaulatan untuk Rakyat, Banclung : Mizan, 1998

Harun Hacliwiyono, Sari Sejarah Filsaffat 2, Yogyakartal : Kanisius 1980

Nurcholish Madjicl, Islam Agama Kemanusiaan, Membangun Tradisi dan Visi Baru Islam Inclonesia, Jakartal : Palramadina, 1995

Masykuri Abclillah, Demokrasi di Persimpangan Makna, Yogyakartal : Tiarara Wacana, 1999.

Abcl. Wahab Khallaf, Ilm Usul al-Fiqh, Kuwait Dar alQallam, 1978

Abu Zahrah, Usul al-Fiqh, Darr al-Qalam al-Arabi, t.t. Ali Yafie, "Hak Indlividu dan Masyarakat clalam Khazanah Pesantren”, Pesantren, Vol. IV, No. 11978

Bassam Tibi, "Islamic Law/Sharri'a and Human Rights : International Law and International Relations" clalam Tore Linclholm and Kari Vogt (ed.) Islamic Law Reform and Human Rights, Oslo : Nordlic Human Rights Publication, 1993.

Greg Barton, "Indonesia's Nurcholish Madjicl and Abdurrahman Wachicl as Intellectual Ulama' : The Meeting of Islamic Traditionalism and Modernism in Neo-Modernist Thought" Studia Islamika, Vol.4, No.1, 1997.

Abu Ishaq asy-Syatibi, al-Muwafaqat fi Usul al-Abkam Jilid I, (Dar al-Rasyad al-Hadlisah, t.t. 